原

教室に扣ける朠囊胞症例の画像診断と外科的治療の検討

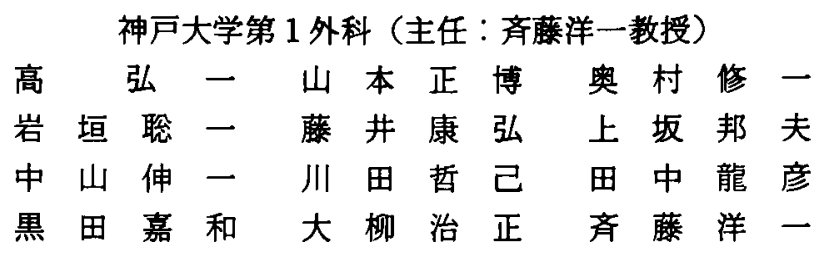

教室の最近13年間の䐙軍胞36症例につき，特に画像診断と治療の面より検討を加えた。 腹部エコー, CT では炎症性要胞は内部構造を認めることは少ないが, 睡疡性衰胞では多

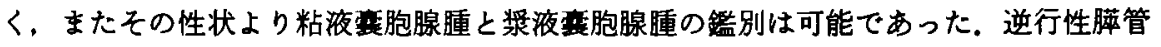
造影は, 胼管系の全体像を把握し, 術式決定上重要であった。血管造影は, 炎症性衰胞

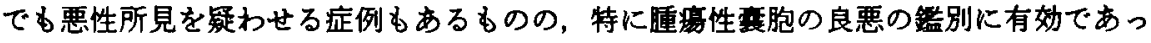
た。

治療は，炎症性垔胞では内瘦術が最も多く，背景となる慢性苹炎に対する処置として，

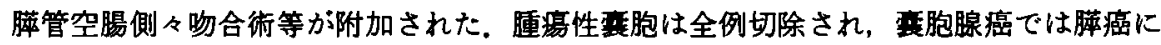
準じた術式が施行された。炎症性袁胞の術後遠隔成樍は, 症状の軽快率83.2\%, 就労率 $70.6 \%$ と良好であった。また変胞腺癌 3 例は最長 4 年10カ月を経過したものを含めて全 例健在である。

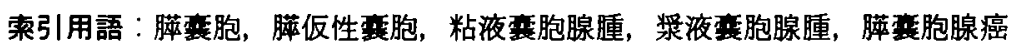

I.はじめに

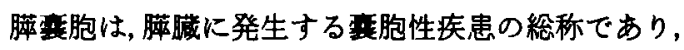
従来比較的稀な疾患と考えられてきたが，近年特に腹 部エコー,CT 等の画像猃断の進歩とともに, その発見 頻度は増加しつつある。しかし䐙衰胞の成因は，炎症 性, 外傷性, 眝留性, 畽汮性など多岐にわたっており， その質的診断については，各病態における画像診断上 の特徵についてて詳細な検討を要する。また治療法の選

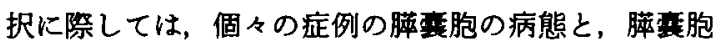
が形成されるに至った膵病変の背景を熟知することが 極めて重要であると考学られる。

当教室では最近13年間に苹要胞36例を経験し，その 診断と治療, 術後遠隔成績につき検討を加えたので, 文献的考察とともに報告する。

\section{II. 対 鼠}

1973年 1 月より，1985年12月までの13年間に当教室 で経験した膘垔胞は36例であった。 その内訳は仮性震 胞27例，真性莗胞 9 例で，その成因としては，炎症性

昭和61年 9 月 24 日受付 62 年 1 月 29 日採用

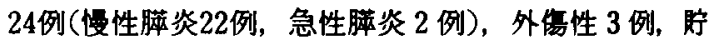
留性 2 例, 尰掦性 7 例（粘液至胞腺腫 3 例, 浆液宾胞

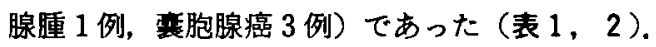

これらの櫒豪胞症例を対象に年龄, 性別, 臨床症状 ならびに腹部ェコー, CT, 血管造影等の画像診断及び その治療と術後遠隔成績について検討を加えた。

表 1 教室における愺菖胞

\begin{tabular}{|c|c|c|}
\hline 程 類 & 成 因 & 例 数 \\
\hline \multirow[t]{2}{*}{ 仮性衰胞 } & 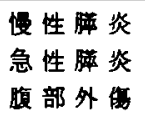 & $\begin{array}{r}22 \\
2 \\
3\end{array}$ \\
\hline & 小計 & 27 \\
\hline \multirow[t]{2}{*}{ 真性票胞 } & 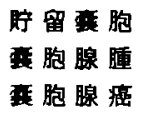 & $\begin{array}{l}2 \\
4 \\
3\end{array}$ \\
\hline & 小計 & 9 \\
\hline 総 & 計 & 36 \\
\hline
\end{tabular}


衰 2 教案における真性家胞

\begin{tabular}{|c|c|c|c|c|c|c|}
\hline 例 & 臨床症状 & 発生部位 & 大きさ & 手術術式 & 病理診断 & 予 \\
\hline 1. 53 紫 우 & 上胙部痛 & 体 部 & $1.0 \mathrm{~cm}$ & 莫 胞 摘 除 術 & 眝留克胞 & (生存中 \\
\hline 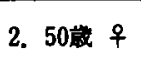 & 腹部運痹 & 体 尾 部 & $17 \times 17 \mathrm{~cm}$ & 胼体尾部切除術 & 眝留暴胞 & (生存中 \\
\hline 3. 44葴 우 & 榎部膨满感 & 体尾 部 & $15 \times 16 \mathrm{~cm}$ & 㭗体尾部切除術 & 粘液咅胞腺尰 & (生荐虫 \\
\hline 4. 39 葴 우 & 上腹部痛 & 体 & $2 \times 2 \mathrm{~cm}$ & 胼体尾部切除術 & 粘夜蒦胞腺腫 & 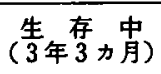 \\
\hline 5. 36筬 우 & 左季助部痛 & 尾 & $6.0 \mathrm{~cm}$ & 羘尾部切除術 & 粘液玨胞腺腫 & $\begin{array}{l}\text { (生存 中 } \\
\text { (年10力月) }\end{array}$ \\
\hline 6. 73瓽 $\hat{\alpha}$ & 奀季助 部 & 頭 & $2.9 \times 2.0 \mathrm{~cm}$ & 指腸切除 & 㢡液烡胞腺腫 & 生 \\
\hline 7. 40胔 우 & 左側腹部痛 & 体尾 部 & $15 \times 12 \mathrm{~cm}$ & 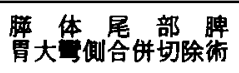 & 基胞腺瘦 & 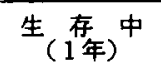 \\
\hline 8. 71瓷 우 & 上腹部腫塁 & 頭 & $10.0 \times 8.0 \times 5.5 \mathrm{~cm}$ & 辟眽合垪切除㒀 & 重胞腺痖 & 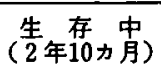 \\
\hline 9. 60䠞 우 & 上腹部痛 & $\begin{array}{l}\text { 部 } \\
\text { 部 }\end{array}$ & $\begin{array}{r}7 \times 5 \times 4 \mathrm{~cm} \\
6.5 \times 5 \times 3 \mathrm{~cm}\end{array}$ & 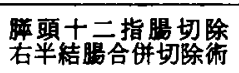 & 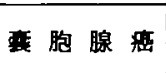 & $\begin{array}{l}\text { 生存 中 } \\
\text { (4年10カ月) }\end{array}$ \\
\hline
\end{tabular}

\section{III. 結 果}

\section{1. 年战, 性}

炎症性衰胞では，男性21例，女性 3 例と男性に多く， 年龄では40歳代に最す多くみられ，その平均年跲は 48.3葴であった。一方真性哄胞は 9 例中 8 例が女性で,

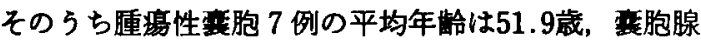

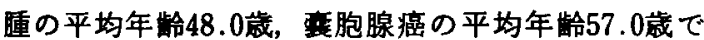
あった．外伤性衰胞では年龄，性別に特徵なく， 3 例 中 2 例はハンドル外傷によるものであった（表 3 ）。

\section{2. 的度症状}

臨床症状を仮性变胞と真性襄胞に分け，対比してみ ると，仮性咅胞では全例に腹痛が認められ，次いで腹

表 3 丵面胞の年龄，性分布

\begin{tabular}{|c|c|c|c|c|c|c|c|c|}
\hline \multirow{2}{*}{ 年 此 } & \multicolumn{2}{|c|}{ 奖泟 性 } & \multicolumn{2}{|c|}{ 外 性 } & \multicolumn{2}{|c|}{ 拧 留 性 } & \multicolumn{2}{|c|}{ 畽癌 性 } \\
\hline & 男 & 女 & 男 & 女 & 男 & 女 & 男 & 女 \\
\hline$<20$ & & & & 1 & & & & \\
\hline \multicolumn{9}{|l|}{$21 \sim 30$} \\
\hline $31 \sim 40$ & 4 & 1 & & & & & & $3(* 1)$ \\
\hline $41 \sim 50$ & 10 & 1 & & & & 1 & & 1 \\
\hline $51 \sim 60$ & 3 & & 1 & & & 1 & & ${ }^{* 1}$ \\
\hline$>61$ & 4 & 1 & 1 & & & & 1 & ${ }^{\prime 1}$ \\
\hline \multirow{2}{*}{ 竍 } & 21 & 3 & 2 & 1 & 0 & 2 & 1 & 6 \\
\hline & \multicolumn{2}{|c|}{24} & \multicolumn{2}{|c|}{3} & \multicolumn{2}{|c|}{2} & \multicolumn{2}{|c|}{7} \\
\hline
\end{tabular}

部腫瘤，発熱，体重減少，呕気，呕吐等の消化管王迫 症状，さらに頻度は少ないが，総胆管末端の㔺胞の圧 排による黄㾝や，苹珄胸水などがみられた。一方真性 要胞では，腹痛は 9 例中 4 例 $(44.4 \%)$ と仮性苝胞に くらべ少なく，腹部腫瘤が 9 例中 4 例 (44.4\%) と高 頻度に認められ，そのらち 3 例は腹痛を伴わない腹部 畽瘤を主訴とした。 その他発熱などの炎症症状む少な く，仮性荎胞との間に臨床症状に若干の違いが認めら

表4 膵蜠胞の自・他賞症状

\begin{tabular}{|c|c|c|}
\hline 症 状 & $\begin{array}{c}\text { 仮性重胞 } \\
\text { (27例) }\end{array}$ & $\begin{array}{c}\text { 其牲垔胞 } \\
\text { (9例) }\end{array}$ \\
\hline 痛 & 27 & 4 \\
\hline 腹 部 弫 瘤 & 6 & 4 \\
\hline 発熱 & 6 & 1 \\
\hline 体重減少 & 7 & 1 \\
\hline 呕気・呕吐 & 7 & 1 \\
\hline 食欲不振 & 3 & 0 \\
\hline 全身倦总忽 & 3 & 1 \\
\hline 背 部 痛 & 3 & 1 \\
\hline 瘨 & 3 & 0 \\
\hline 腹部膨满感 & 3 & 2 \\
\hline 濑 & 2 & 1 \\
\hline 呼 吸 困 難 & 1 & 0 \\
\hline 水 & -1 & 0 \\
\hline
\end{tabular}


れた（表 4 ）。

3. 画像診断

上部消化管透視では, 腪変胞による胃の圧排所見や， 十二指腸脚の開大等の所見が29例中18例（62.1\%）に 認められた。

腹部エコーでは，検查を施行した 32 例中 28 例 (87.5\%) に湿胞の描出が可能であった。描出できな かった 4 例は，当科にて腹部超音波検査を始めた初期 の例に多く，多房性のためや内容が膿性のため充実性 腫瘤と誤診されたすの 2 例，腸管ガスのため描出でき なかったもの 2 例であった. 最近では䐙体部の径 1.0 cmの小蒙胞まで描出されており，はとんとの症例で 言胞の描出が可能となっている，茦素胞の質的診断面 より描出された膵变胞の内部ェコー像を検討すると， 炎症性変胞では，震胞の描出できた16例中 3 例 (18.8\%)には，要胞内腔へ突出する腫瘤状陰影が認め られたが，他の13例（81.3\%）は均一な低ェコーレべ ルを示した。これに対して腫瘍性要胞では 7 例中 5 例 (71.4\%)に隔壁や，不規則内部エコー分布などが認め られた（表 5)。をたその内部ェューの性状としては， 粘液亚胞腺腫 3 例では隔壁構造が主であったのに対 し，浆液蒦胞腺腫 1 例では，網状または蜂巣状構造を 示した（図 1，2）。しかし粘液墔胞腺腫と衰胞腺癌に

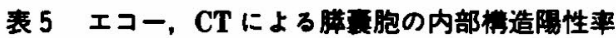

\begin{tabular}{c|c|c|c|c}
\hline & 炎症性 & 外侮性 & 詝留性 & 尰湯性 \\
\hline エコー & $3 / 16(18.8)$ & $1 / 3(33.3)$ & $1 / 2(50)$ & $5 / 7(71.4)$ \\
\hline CT & $3 / 15(20)$ & $0 / 3(0)$ & $0 / 1(0)$ & $4 / 6(66.7)$ \\
\hline \multicolumn{4}{|c}{ ( )内は\% }
\end{tabular}
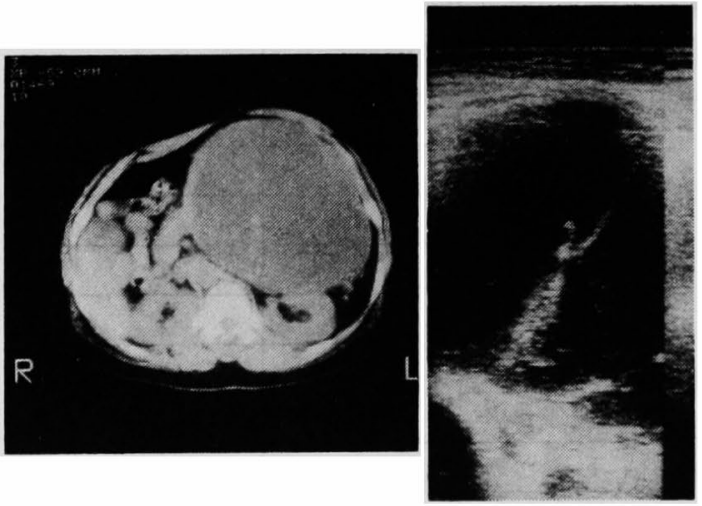

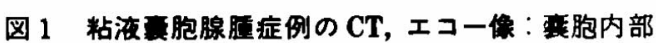
に隔壁様構造を認める。

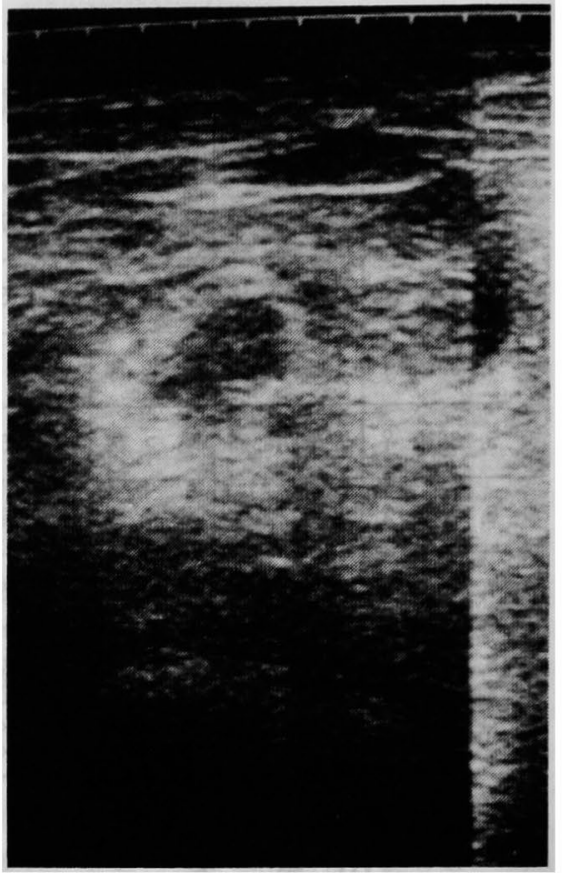

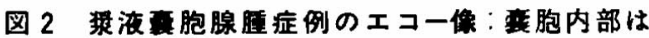
reticular patternを示す.

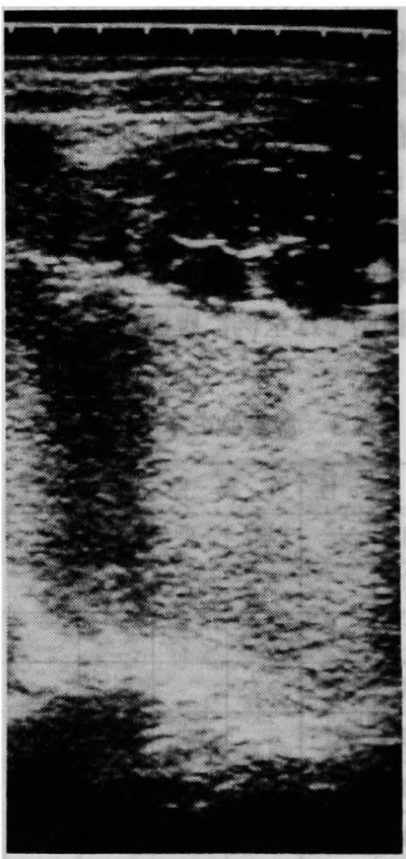

图 3 胞腺瘭症例のエコー像：多房性のエコー像を 示し，粘夜咅胞腺腫と鑑別困難。 
は土コー像に差はなく、エコー上鑑別困難であった（図 3 ).

腹部 CT では，検查施行された25例全例に丧胞の描 出が得られた. 内部構造の面より検討すると炎症性栾 胞15例中12例（80\%）は均一な low density を示した か， 3 例 (20\%) は恋胞壁の不整や䔶胞内腔へ突出す る畽瘤陰影のために腫瘍性咅胞との鑑別が困難であっ た。一方尰瘍性变胞では 6 例中 4 例 $(66.7 \%$ ）に，内 部構造を認め(表 5)，その性状としては，粘液竞胞腺 腫 3 例では隔壁構造が主で，浆液震胞腺腫 1 例ではェ ソハンスにより，不規則な網状一斑状の内部構造が得

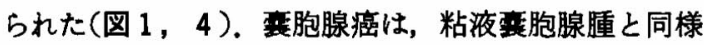
の CT 像を示した（図 5）が，エンハンスにて变胞内 部の腫瘤様陰影か;，広範囲に high density に描出され た例では悪性が強く礙われた（図6).

羘管造影所見では炎应性政胞で17例中 8 例

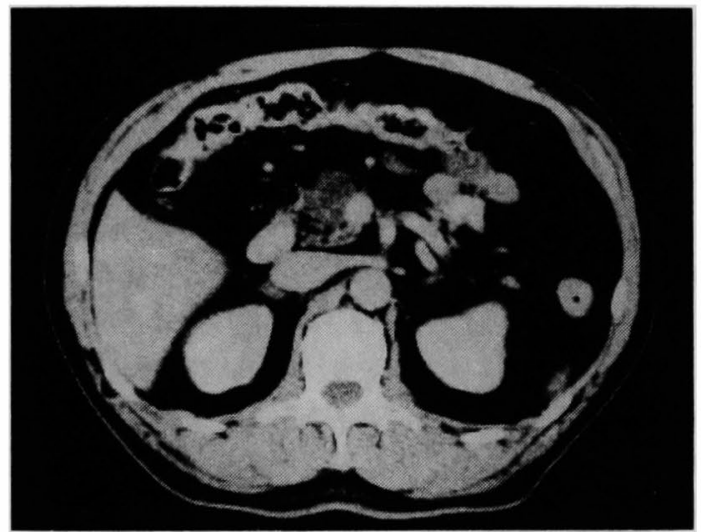

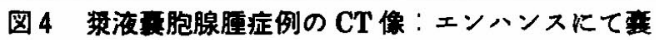
胞内腔に不規則な斑状一網状影が出現。

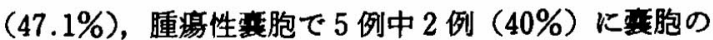
造影が得られ(表 6, 図 7)，両者の鼠胞造影陽性率に 差はなかった，京胞造影陰性例16例中 6 例（43.5\%） は嵫管閉塞や，苹管王排等の所見が認められたが，蓄 胞不明の症例む10例と全体の $23.1 \%$ 占めた。その他， 资症性变胞では主羘管の払張，腪石などの慢性䐙炎の 所見が得られた。

炎症性竞胞の血管造影所見としては，血管の圧排像 が主体で，20例中14例（70\%）に認められた。腫搷血 管の増生は認められず，腫湯性萑胞との鑑別上重要で あると思われる。しかし，大きな羮胞では門脈脾静脈 の狭窄や，炎症性変化によると思われる血管浸蝕像む 5 例に認められ，このような例では，悪性病変を完全

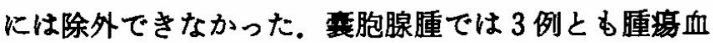
管の増生はなく，血管の王排像のみであった。䒼胞腺 癌例では全例腫瘍血管の増生を認め，そのうち2 例は 血管漫蝕像より悪性と診断された(図 8)。他の 1 例は 血管造影上悪性所見は得られなかったが，これは流胞 腺尰の上皮内に砤小な癌巣を認めた症例であった（表 7 ).

\section{4. 治㬌}

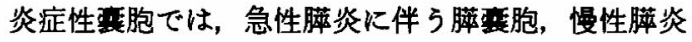
の急性増悪例で現在経過観察中のもの及び手術拒否の 3 症例を除いて全例に手術が施行された.手術術式は, 内瘦造設術が最も多く 8 例（裏胞空腸吻合術 5 例，婁 胞胃吻合術 1 例, 变胞十二指腸吻合術 2 例)，次いで外 瘦造設術 4 例, 要胞膵管空腸側々吻合術 4 例, 膵尾部 切除術 2 例, 膵頭十二指腸切除術 1 例, 膵尾側切除術 に克胞空腸あるいは膵管空腸側々吻合術を加えたるの が各 1 例づつであった(表 8 )。 ）なた变胞による総胆管 末端の圧排㹟窄のみられた症例に総胆管十二指腸吻合

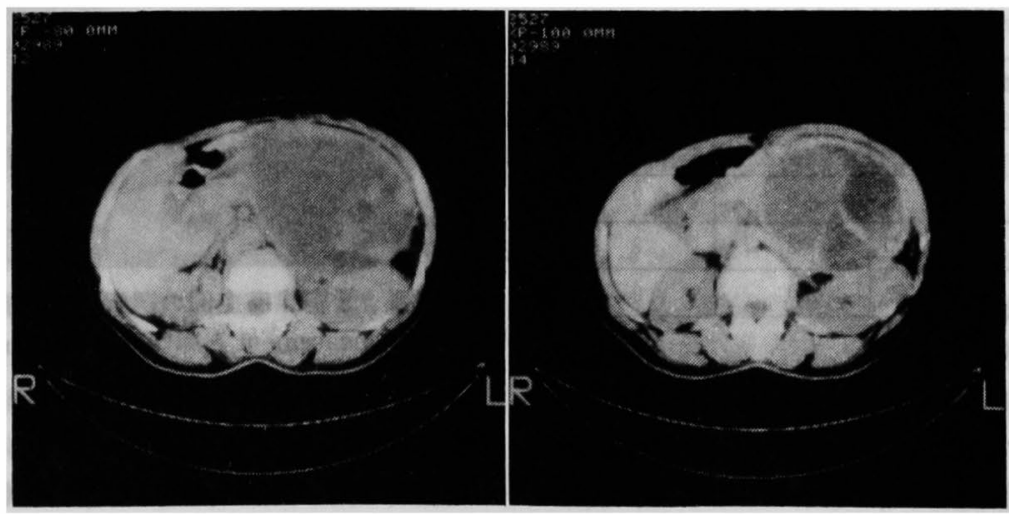

図 5 胞腺密症例の CT 像：壁在結節様あるいは隔壁様構造が認められる。 


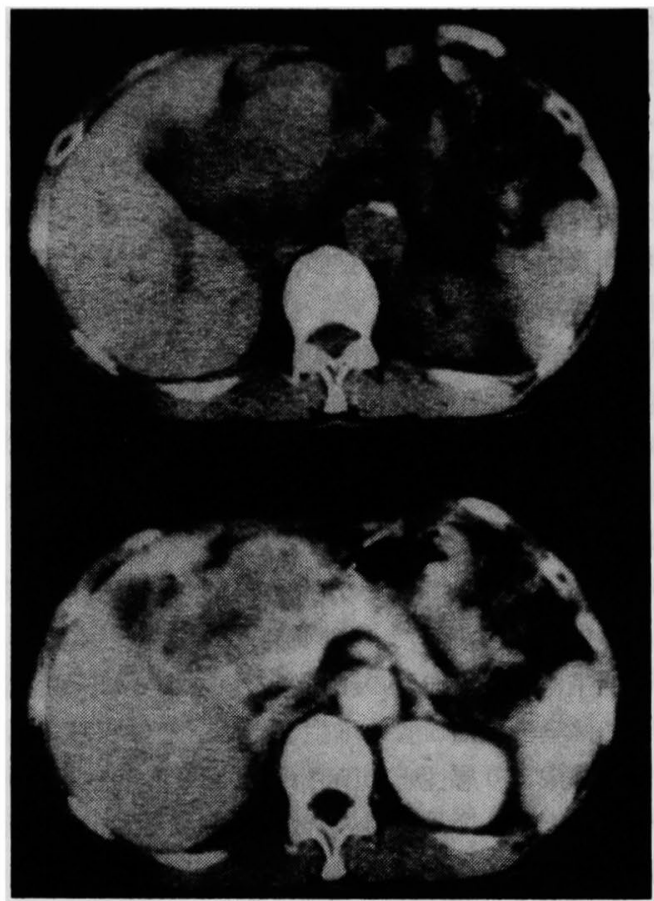

图 6 胞腺症症例の CT 像 : 苹頭部の比較的均一な low density area が，エンハンスにより不規則広範 な尰瘤影を示した。

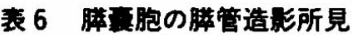

\begin{tabular}{|c|c|c|c|c|c|}
\hline & 炎症性 & 外賃性 & 眝留性 & 腫㛫性 \\
\hline \multicolumn{2}{|c|}{ 咅胞造影陽性 } & 8 & 0 & 0 & 2 \\
\hline \multirow{3}{*}{ 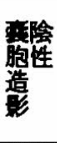 } & 羘管閉塞 & 3 & 1 & 0 & 0 \\
\hline & 羘管压排 & 1 & 0 & 0 & 1 \\
\hline & 桽胞不明 & 5 & 2 & 1 & 2 \\
\hline \multicolumn{2}{|r|}{ 計 } & 17 & 3 & 1 & 5 \\
\hline
\end{tabular}

言 7 櫒胞の血管造影所見

\begin{tabular}{|c|c|c|c|}
\hline & 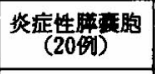 & 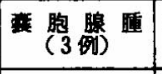 & 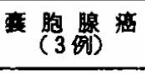 \\
\hline 㬈蒠管增生 & 0 & 0 & 3 \\
\hline 血管 漫 像 & 5 & 0 & 2 \\
\hline 压排像 & 14 & 3 & 3 \\
\hline 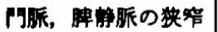 & 2 & 0 & 0 \\
\hline
\end{tabular}

術, 胸水のみられた症例に対して右後縰隔ドレナージ がそれぞれ附加された。

外傷性变胞は，自然消失 1 例，外藻造設訹 1 例，竞 胞摘除術（横行結腸合併切除）1例であった。

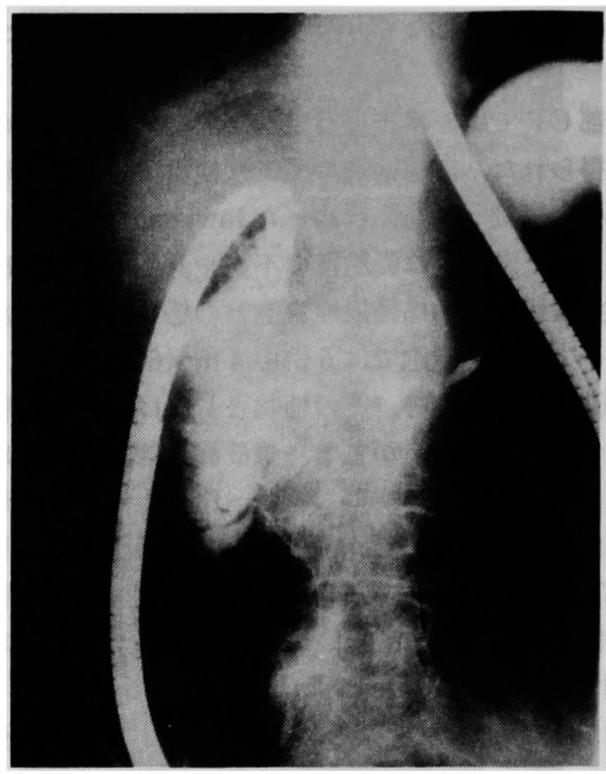

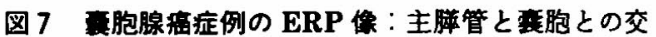
通があり，襄胞内に不規則な造影剤のたまりがみら れる.

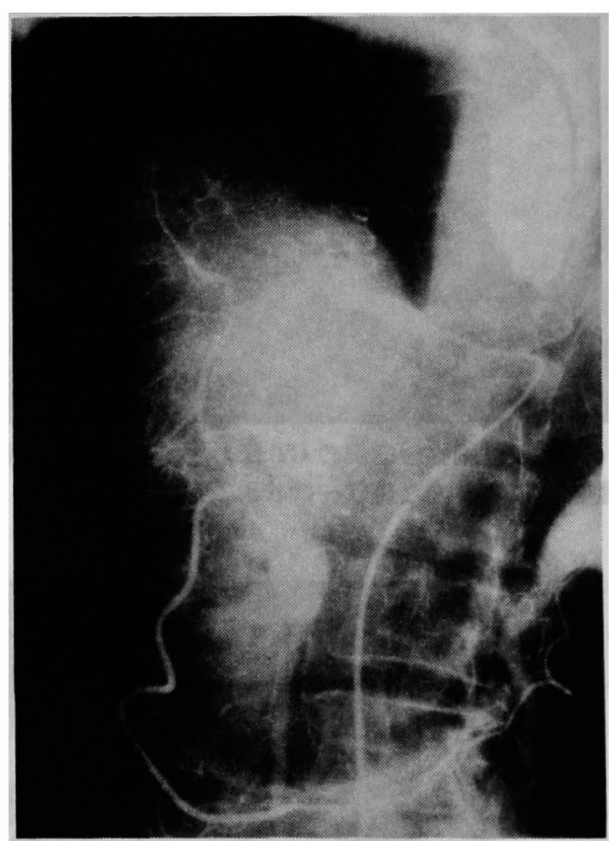

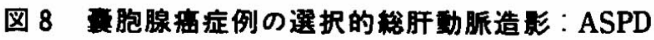
に encasement と荤頭部に fine tumor vessels を認 める.

真性音胞は全例切除され，特に变胞腺癌では，胃，

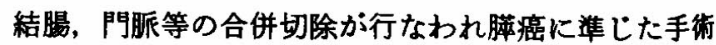




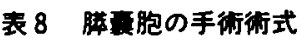

\begin{tabular}{|c|c|c|c|}
\hline 手術術 式 & 资 症 性 & 外性 & 真 \\
\hline 造 設 術(5) & 4 & 1 & 0 \\
\hline 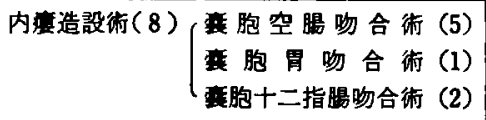 & $\begin{array}{l}5 \\
1 \\
2\end{array}$ & $\begin{array}{l}0 \\
0 \\
0\end{array}$ & $\begin{array}{l}0 \\
0 \\
0\end{array}$ \\
\hline 傽 管 空、渴 側 \& 吻 合 術 (3) & 3 & 0 & 0 \\
\hline 䐙管空腸側々吻合術＋霍胞空腸吻合術 (1) & 1 & 0 & 0 \\
\hline 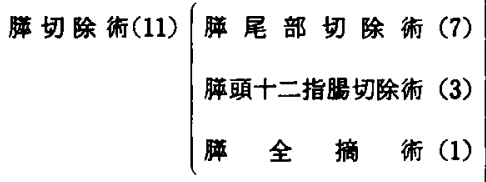 & $\begin{array}{l}2 \\
1 \\
0\end{array}$ & $\begin{array}{l}0 \\
0 \\
0\end{array}$ & 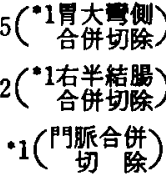 \\
\hline 䐙体尾部切除術+咅胞空腸吻合術 (1) & 1 & 0 & 0 \\
\hline 膦尾部切除術＋胼管空腸側 々吻合術 (1) & 1 & 0 & 0 \\
\hline 摘除術 (2) & 0 & •1(黄行結腸) & 1 \\
\hline 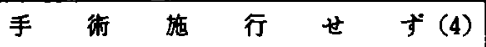 & 3 & 1 & 0 \\
\hline 36 & 24 & 3 & 9 \\
\hline
\end{tabular}

が施行された（表 8).

\section{5. 衍後薏陆成嚗}

手術が施行された炎症性膵昰胞症例で予後調査の可 能であった17例について，その遠隔成績を検討すると， 17例中疼痛の消失ないし軽快したるの15例（88.2\%） と自覚症状の良好な改善がみられ，就労状況む良好で あった，他院に入院中の症例が 3 例あり，これは 2 例 がDM のコントロールのため，1 例は肝炎のためであ る. 再発の 1 例は, 斐胞空腸吻合術施行後, 約 1 年 6 カ月にて疼痛が再発し，このため他院にて腪全摘術が 施行された症例であった（表 9).

真性落胞は全例健在であり, 特に裴胞腺癌は最長 4 年10カ月を経過したすのを含めて，全例再発の徵候を 認めていない。

\section{IV. 考按}

膵要胞は諸家によって，いくつかの異なった分類が されている. Mahorner ${ }^{1)}$ Cattel $^{2)}$ らは, 成因に基つい た分類法を採用している.他方, Fallis ${ }^{3)}$ Howard”ら は従来の通り真性と仮性に大別し，さらにこれらを成 因的に考虑した分類法を行っている. 特に Howard ら の分類は病理学的に丧胞の形態をよく表現しているの みでなく，治療にす直結しており，本稿もこの分類法

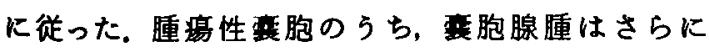

\section{表 9 炎症性愺莫胞の街後経過及ひ就労状況}

\begin{tabular}{|c|c|c|c|c|}
\hline \multicolumn{2}{|c|}{ 疼痛の消失ないし毦块 } & \multirow{2}{*}{ 15例 } & \multirow{2}{*}{ 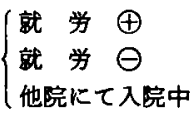 } & \multirow{2}{*}{$\begin{array}{r}12 \text { 例 } \\
1 \text { 例 } \\
3 \text { 例 }\end{array}$} \\
\hline 不 & 変 & & & \\
\hline 再 & 吐 & 1例 & & \\
\hline 不 & 明 & 1例 & & \\
\hline
\end{tabular}

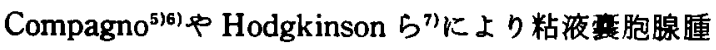

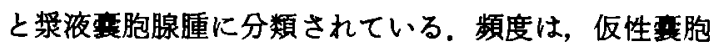
が最も多く，䑏堡胞全体の50〜90\%を占め，その成因 別内訳では膵炎によるあのが50～90\%と多く，外㑺性

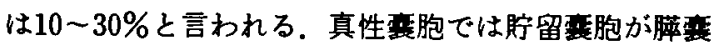
胞全体の10 30\%を占め, 腫瘍性趇胞むやはり 10〜30\%ぐらいの頻度と報告されている ${ }^{899}$. 当教室の 症例もほぼ同様の傾向を示した，年龄，性別を検討す

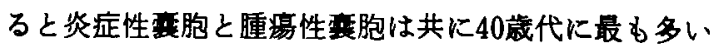
が10－20歳代では，资症性垔胞がほとんど見られない のに対し，腫煬性要胞，特に荎胞腺腫はかなりの頻度 でみられる。また炎症性覆胞は一般に男性に多く，真

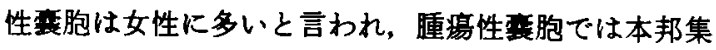
計例で竞胞腺腫78例中男:女 $=18: 61$, 垔胞腺癌76例

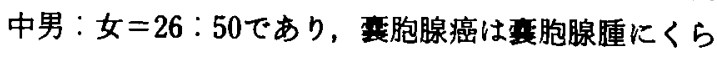
へ，やや男性の比率が増し，高年龄層に多いと報告さ 
れている(0).

膘垂胞の臨床症状では，仮性要胞では腹痛が最も多 く，80 90\%にみられ，次に腹部腫瘤が70～80\%と多 く，その他発熱，体重減少，呕気呕吐，黄㡺，胸水等 あ少なからず認められるる11121.

一方，真性旁胞，特に腫煌性毫胞では，本邦集計例 で，約半数の主訴が腹部腫瘤で，上腹部痛を主訴とす るものが, 約 $30 \%$ と報告されている(10)ことから,腹痛等

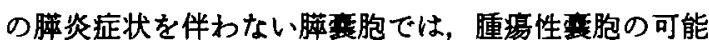
性を充分考虑する必要がある。

近年，画像診断の著しい進歩により，膵囊胞の存在 診断は容易となったが，質的診断，特に良悪の鑑別は 末だ十分でない。

上部消化管透視では，当科では62.1\%に胓毣腫によ る圧排所見を認めたか，諸家の報告でも48〜 76\%に異 常所見を認め1113114)，䐙咅胞の発見にはルーチンに行 なわれる胃透視の際にも苹要胞の存在を念頭にお゙く必 要があると思われる。

腹部エコーでは最近では最小 $5 \mathrm{~mm}$ まで描出可能と 言われており ${ }^{15)}$, 当科では最小 $10 \mathrm{~mm}$ であったが，腸管 ガスの影響等なければ，大体その程度まで描出可能と

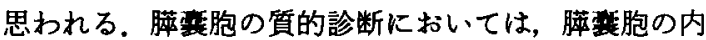
部エコ一像が重要である。守田ら ${ }^{161}$ は, 炎症性趸胞のエ コ一像につき検討し，慢性苹炎に合併する謇胞は大部 分が5cm 以下の無ェュー性の pattern を示すのに対 し，急性膵炎あるいは慢性苹资再然期に形成される定 胞は， $5 \mathrm{~cm}$ 以上が多く，その半数は血液，凝血塊，膿 性液等の襄胞内容のため，様々なエコーレベルと不規 則分布の内部エコーが認められたと述べている。一方,

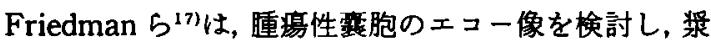
液蒦胞腺腫は， ほとんどが $2 \mathrm{~cm}$ 以下の小震胞の集合で あるためその内部ェコーは, hypoechoic と echogenic areas の混合であるのに対し，粘液襄胞腺腫では $5 \mathrm{~cm}$ 以上の大きなCyst よりなる多房性あるいは単房性の 覀腫で，厚い明瞭な被膜を持ち隔壁や内腔へ突出する 隆起を伴うと述へ，両者のェュー上の違いを指摘して いる. 当科の症例です炎症性要胞では内部ェコーを認 めることは少なく，腫煬性变胞では多いと言えるが，

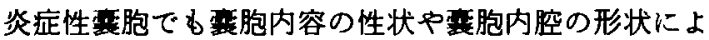
ク内部エコーを認める例もあり，鑑別診断上困難な例

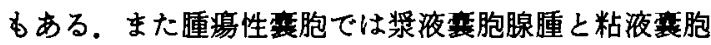
腺腫は異なるェコ一像を示し，今後鑑別喰断上留意す べきと思われる。

腹部 CT では，大友ら ${ }^{18)}$ は腫煬性震胞 6 例の CT 上

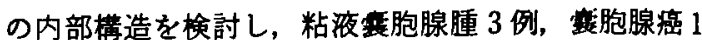

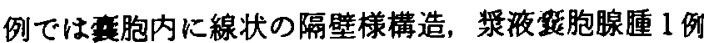
では網状の不規則な内部構造を認めたが，粘夜菖胞腺 腫之咅胞腺癌を腫瘍自体の CT 像から鑑別する根执之 なる所見は見出せなかったとしている．当科の症例も 同様の所見を示し，進行してかなり腫瘤部分の增大し た裹胞腺癌以外は粘夜变胞腺腫と鑑別は困難であっ た。ささらに大友らは脺仮性要胞24例では内部構造を認 めた症例はなかったと述へているか，仮性要胞の完成 途上にあるすのでは不鮮明な隔壁様陰影や壁在結節状 の突起物を伴うこともある ${ }^{199}$ と言われており，教室の 症例でも炎症性要胞でCTを施行した15例中多房性で

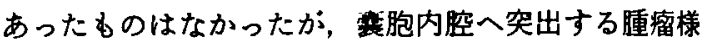
陰影のため腫啺性票胞か疑われたものが 3 例あった。

以上, ェュー, CT 等の画像診断では各種膵崔胞の病 理病態の深い理解に基づいて特にその内部構造を注意 深く観察し，実際の構造と比較検討すればさらに鑑別 か容易になるである5と思われる201.

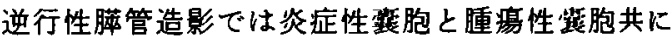
40５0\%の萇胞造影陽性率であった。しかし，ほぼ同 率に曹胞不明の症例も認められ，望胞の局在診断には エコー, CTにくらべ劣ると思われた. しかし，䐙管系 の全体像を把握し，特に慢性脺炎の合併する場合は， その程度や抝がりを明らかにし，術式を決定する上で 重要な検査法であった。

選択的腹腔動脈造影において，炎症性咅胞では，動 脈相にて压排所見，毛細管相では無血管領域として描 出され，震胞壁が均一に薄く染まる例が多い，腫場性 彭胞ではこれまで hypervascularityを示すものがは とんどと思かれていたが，最近では腫場血管が豊富に 認められる例は85\%前後であるとい5報告もみられ

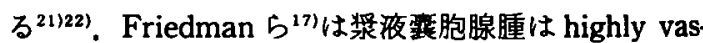
cular であるか，粘液篅胞腺腫は hypovascular な場合 が多く，特に竞胞壁や内腔への隆起に一致したわすが な neovascularity と encasementがみられるときは

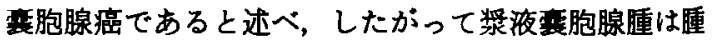
瘍濃染像を示す non-functional islet-cell tumor と, 粘 液垔胞腺腫は仮性变胞との鑑別が，必要であると述べて いる，救室でも血管造影を施行した阽液婁胞腺腫 3 例 はすべて hypovascular を示した，烡胞腺癌は全例腫 瑒血管の增生を示し， 2 例は encasement の所見から 悪性と診断が可能であった，他の 1 例は，襄胞腺腫の 上皮内に潜む微小癌であった。しかし，炎症性黄胞で る20例中 5 例に炎症によると思われる encasement を 
示したことから，良悪の鑑別上留意すべきと思われる． 仮性要胞に対しては Bradley ら ${ }^{231}$ は，自然治等か554 例中11例 $(20.4 \%)$ におこり，その5ち10例は発症後 6 週以内に消失し， 7 週以上の長期覞察では逆に要胞 の破裂，穿孔，感染などの重篤な合併症が高くなると している. またWarren ら24は，彼の実験から安定し た䨢胞壁の完成には 4 6 週要すると述べている。一 般には，自然治瘦の可能性，合併症の問題，内瘦にた えらる变胞壁の形成等を考㦄し，4－6週は保存的治 療を行らのが妥当であろう，自験例でる炎症性信胞と 外倁性栾胞の各 1 例か， 4 週前後の保存的治療の結果,

自然消失している。

仮性变胞の外科的治療としては，摘除ないしは襄胞

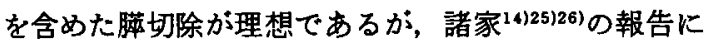
あるよ5に実際は羘及び周囲組織との疮着が強く，過 大侵襲となるためドレナージ術を行らことが多い，自 倹例では仮性衰胞が切除された症例は23例中 6 例で， 䐙尾部に限局し，周囲との瘦着の少なかった 4 例に苹 尾側切除術が，害胞腺癌が疑われた 1 例に膵頭十二指 腸切除が施行された。このように周囲と䈍着の少ない 限局した襄胞や，悪性と鑑別のつかない要胞，襄胞内 出血などでは切除術が適応となる。その他の症例では 内瘦術が適応となるが，变胞内容が膿性であったすの や，庱着の高度であった 5 例に対しては外瘦術が施行 された. 内漠術は 7 例施行され, 対象缄器の選択は軎 胞との解剖的位置関係により最も自然な距離にある䁍 器が採用された。最近水本ら ${ }^{27283)}$ は, 実験的および臨床 的検討から，内瘦術の効果は一時的であり，このため ェコー下の経皮的衰胞ドレナージの有効性を説いて拉 り，今後考虑していく必要があると思われる。李た， 䐙管の抎張や脺石などを伴ら症例には，要胞の背景と しての慢性膵炎に対する処置として, 慢性苹炎の手術 適応 ${ }^{29) 30}$ に従って，苹管空腸側々吻合術等の術式が附 加される必要がある。

真性要胞，特に腫湯性咅胞は切除が原則である。震 胞腺腫は病理学的に㫽液要胞腺腫之粘液毫胞腺腫に分 類され，前者は悪性化はみられないのに対し，後者は malignant potential を有す5(6)7)と言われており，芸胞 壁の完全摘除が必要である。また術前に良悪の判定が 困難なことが多く、震胞壁、リンパ節等の術中司速組 織診を積極的に行い，漫潤性のものやリンパ節転移の みられるすのでは苹癌に準じた手術を施行すべきであ ろ.

当科における炎症性童胞の術後遠隔成績は症状の軽
快率 $83.2 \%$ ，就労率70.6\%と良好であった。症状の不 変例は篹胞胃吻合征施行例で，現在のところ禁酒を含 めた内科的治療にてコントロール可能である. また慢 性䐙炎の病態が進行し，疼痛の再発した症例も1例に 認められたことより，慢性䐙炎による芽震胞の治療に 際しては，慢性胓炎の病態を十分に把握した上での術 式選択が必要であると考えられた。

要胞腺癌は，羘管癌にくらべ予後良好といわれ，

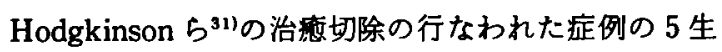
率は68\%であるといら報告るあるすのの，和田ら 本邦での集計に上ると 5 年生存は53例中 2 例に過ぎ ず, 腫場切除後の再発死亡る少なくないと考えられる。 自験例では幸い垔胞腺癌 3 例之す術後最長 4 年10力月 を経過した現在健在であるが，今後笡重な経過観察を 䊦ける必要がある。

\section{V. 結語}

当科にて経験した膵赛胞36例の診断と治㞠につい

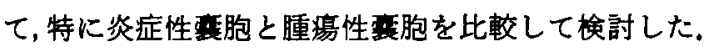

羘要胞の質的診断について種々の画像診断における 役割とその特徵を明らかにしたが, 腫湯性襄胞の診断, 特に良悪の判定はいまだ十分でなく,術中迅速組織診, あるいは切除標本の十分な病理学的検索が必要であ る.

また治療面では，炎症性要胞では，その背景にある 膵の病態を十分に把挃することが重要で，個々のヶー スに応した治療法を選択する必要がある，襄胞腺腫は その malignant potential を考虑し，表胞完全摘除が 原則であり，悪性のものでは腪癌に準じた手術必要 である。

本論文の要旨は1984年第24回日本消化器外科学会総会に おいて発表した。

\section{文献}

1) Mahorner, H.R. and Mattson, H.: The etiology and pathology of cysts of the pancreas. Arch. Surg., 22 : 1018-1033, 1931.

2) Cattel, R.B. and Warrer, K.W.: Surgery of the pancreas. Pancreatic cysts. Saunders, Philadelphia, 1953, 156-204.

3) Fallis, L.S. and Barrion, J.: Pancreatic cysts. Am. J. Surg., 86: 255-259, 1953.

4) Howard, J.M. and Jordan, G.L.: Pancreatic Cysts, Surgical Diseases of the Pancreas, Lippincott, Philadelphia-Montreal, 1960, 283 -320 . 
5) Cimpagno, J. and Oertel, J.E.: Microcystic adenomas of the pancreas (glycogen-rich cystadenomas). - A clinicopathologic study of 34 cases-. Am. J. Clin. Pathol., 69 : 289-298, 1978.

6) Compagno, J. and Oertel, J.E.: Mucinous cystic neoplasms of the pancreas with overt and latent malignancy (cystadenocarcinoma and cystadenoma). -A clinicopathologic study of 41 cases - . Am. J. Clin. Pathol., 69: 573-580, 1978.

7) Hodgkinson, D.J., ReMine, W.H. and Weiland, L.H. : Pancreatic cystadenoma. -A clinicopathologic study of 45 cases - Arch. Surg., 113 : 512-519, 1978.

8）宮崎逸夫，藤田秀春：VII-4捇衰胞. 䐙喴の研究， 内藤聖二編, 同文专院, 東京, 1983, 777-800.

9）小島国次：䐙恶胞の病理, 肝・胆・苹, 4:887-894, 1982.

10）和田祥之，黑田 慧，森岡恭彦他：畽場性䐙要胞之 その外科治療，胆と苹，5:1145-1163，1984.

11）尾畑秀明，古賀明俊，中山文夫他：脑宾胞の診断と 治療一自験24例の検討一，日消誌７9：1164一 1171, 1982.

12）織田耕三，斉藤洋一：綎隔内仮性毫胞の 2 症例と 本邦報告例の検討, 日臨外，46：605-612，1985.

13）中澤三郎，森田敬一，乾 和郎他：膵雯胞および背 景病変の診断の進め方, 胆と脇, 5:1095-1104, 1984.

14）中山和道, 木下寿文, 今村鉄男：炎症性脺高胞に対 する対策一外科の立場から, 胆と苹, $4: 941-947$, 1983.

15）大井 至, 秋本 伸, 鈴木 徫: 膵喓胞の診断一と くに小さな震胞について一，外科， $44 ： 455-462$, 1982.

16）守田政彦, 税所宏光, 大藤正雄他：炎应性嗒要胞に 対する内科の立場一最近の画像診新法の応用をふ

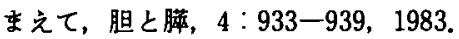

17) Freidman, A.C., Lichtenstein, J.E. and Dachman, A.H. : Cystic neoplasms of the pancreas. Radiology, 149: 45-50, 1983.

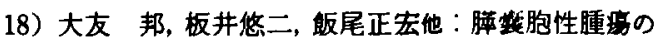
CT 診新，臨放線，28：121-125，1983.

19）板井悠二：CTによる㬸害胞の籃別診新，胆と膦， $5: 1105-1112,1984$.

20) Wolfman, N.T., Ramquist, N.A. and Hopkins, M.B. : Cystic neoplasms of the pancreas : CT and sonography. A.J.R., $138: 37-41,1982$.

21) Pressman, B.D., Asch, T. and Casarella, W.J.: Cystadenoma of the pancreas- $A$ reappraisal of angiographic findings. Am. J. Roentgenol., 119 : 115-120, 1973.

22) Freeny, P.C. and Lawson, T.L.: Cystic neoplasma of the pancreas, In Radiology of the pancreas : Springer, New York, 1982, 514-539.

23) Bradley, E.L., Clements, J.L. Jr. and Gonzalez, A.C.: The natural history of pancreatic pseudocysts : A unified concept of management. Am. J. Surg., 137: 135-141, 1979.

24) Warren, W.D., Marsh, W.H. and Muller, W.H. Jr.: Experimental production of pseudocysts of the pancreas with preliminary of servations on internal drainage. Surg. Gyencol. Obstet. $105: 385-392,1957$.

25）梅山整：䐙英胞の手術手技，外科治㞠， $46: 273$ $-282,1982$.

26）宮崎逸夫，藤田秀春：䐙仮性患胞の診断と治㞠指 針，肝・胆・䏲， $4: 903-910 ， 1982$ 。

27）本本龍二, 安藤芳之, 岩崎 諴地：䐙萲胞の病態上 治療. 第21回日本医学会撛演要旨, 360, 1983.

28）世古口務，佐ヶ木秀俊，水本龍二他：羘仮性保胞の 経過と治療方針，日本堙臟病研究会第15回秋季大 会プロシーディング, $14: 212-213,1984$.

29）川田哲已，山本正博，省藤洋一他：遠隔成耫からみ た僈性脑炎外科治療の検討, 日躁外会誌，45：1565 $-1573,1984$.

30）斉藤洋一：消化器疾患の治療方針と初期治療，消 外, $7: 949-953,1984$ 。

31) Hodgkinson, D.J., ReMine, W.H. and Weiland, L.H. : A clinicopathologic study of 21 cases of pancreatic cystadenocarcinoma. Ann. Surg., $188: 679-684,1978$. 


\title{
STUDIES OF DIAGNOSTIC IMAGING AND SURGICAL TREATMENT ON PATIENTS WITH PANCREATIC CYSTS
}

\author{
Koichi KOH \\ First Department of Surgery, Kobe University School of Medicine
}

A retrospective study of 36 cases of pancreatic cyst treated during the recent 13 years was performed from the aspects of imaging and treatment. Visualization of the internal structure by abdominal echography and CT was rare in inflammatory cysts, but frequent in neoplastic cysts. Differentiation between mucous and serous cystadenoma on the basis of properties was possible. Retrograde pancreatography, which disclosed the entire pancreatic ductal system, was important in determining surgical procedure. Angiography was effective for differentiating between benign and malignant cysts, even though some of the inflammatory cysts suggested malignant findings. The most frequent therapy in cases of inflammatory cyst was internal fistulization, with additional side-to-side pancreaticojejunostomy as a procedure for underlying chronic pancreatitis. Neoplastic cysts were resected in all cases, and the procedure for pancreatic cancer was modified for use in the cases of cystic adenocarcinoma. The remote postoperative results in the cases of inflammatory cyst were satisfactory: symptomatic improvement was found in $83.1 \%$ of patients and occupational rehabilitation in $70.6 \%$. All of the three patients with cystic adenocarcinoma are well, including the one surviving a maximum period of 4 years and 10 months. 